\title{
Current options and perspectives for the topical treatment of atopic dermatitis
}

\section{Aktualne możliwości i perspektywy leczenia miejscowego atopowego zapalenia skóry}

Roman J. Nowicki, Elżbieta Grubska-Suchanek, Magdalena Trzeciak, Aleksandra Wilkowska

Department of Dermatology, Venereology and Allergology, Medical University of Gdansk, Gdansk, Poland

Katedra i Klinika Dermatologii, Wenerologii i Alergologii, Gdański Uniwersytet Medyczny, Polska

Dermatol Rev/Przegl Dermatol 2021, 108, 117-125

DOI: https://doi.org/l0.5। |4/dr.2021. 107283

\section{CORRESPONDING AUTHOR/ ADRES DO KORESPONDENCJI: prof. Roman J. Nowicki \\ Katedra i Klinika Dermatologii, Wenerologii i Alergologii Gdański Uniwersytet Medyczny e-mail: rnowicki@gumed.edu.pl}

\begin{abstract}
Atopic dermatitis is one of the most common chronic and recurrent skin conditions, characterized by a complex genetic background, most commonly occurring in children. Its prevalence is still increasing. Despite existing methods of therapy (emollients, wet-wrap treatment, topical glucocorticoids, topical calcineurin inhibitors, antiseptics, antibiotics, phototherapy, elimination of irritants, patient education), the number of available topical preparations for the treatment of this chronic disease is limited. Topical glucocorticoids are the mainstay of the treatment of inflammatory changes. Calcineurin inhibitors should not be used under the age of two, and in the remaining patients, topical calcineurin inhibitors constitute the second-line therapy. Glucocorticoids can only be used for a strictly defined period of time and become gradually less effective during a long-term treatment (tachyphylaxis). Introduction of new, safe, topical preparations for the treatment of this chronic disease is imperative.
\end{abstract}

\section{STRESZCZENIE}

Atopowe zapalenie skóry jest jednym z najczęstszych przewlekłych i nawrotowych schorzeń dermatologicznych o złożonym podłożu genetycznym. Występuje najczęściej wśród dzieci i liczba jego przypadków wciąż wzrasta. Pomimo wielu metod terapii (emolienty, mokre opatrunki, miejscowe glikokortykosteroidy, miejscowe inhibitory kalcyneuryny, antyseptyki, antybiotyki, fototerapia, eliminacja czynników drażniących, edukacja pacjenta) liczba dostępnych preparatów miejscowych do leczenia tej przewlekłej choroby jest ograniczona. Podstawą leczenia zmian zapalnych są miejscowe glikokortykosteroidy. Inhibitory kalcyneuryny nie powinny być stosowane u pacjentów poniżej 2 . roku życia, a u pozostałych stanowią one drugą linię terapii. Glikokortykosteroidy można stosować tylko przez ściśle określony czas, a podczas długotrwałej kuracji ich działanie staje się mniej efektywne (tachyfilaksja). Wprowadzenie nowych, bezpiecznych miejscowych preparatów do leczenia tej przewlekłej choroby jest konieczne.

Key words: atopic dermatitis, wet-wrap treatment, crisaborole, JAK-STAT inhibitors.

Słowa kluczowe: atopowe zapalenie skóry, mokre opatrunki, kryzaborol, inhibitory JAK-STAT. 


\section{INTRODUCTION}

Atopic dermatitis (AD) is the most common inflammatory dermatosis. The disease is characterized by a chronic and recurrent course, presence of eczema-like lesions on the skin and nagging itching. The complex pathomechanism of the disease includes genetic conditions, environmental factors, microbiome disorders and immune disorders [1].

So far, we do not have any therapeutic methods that would completely cure the disease. The therapy we undertake is aimed at obtaining the longest possible remission of inflammatory changes and relief of pruritus, thus improving the patient's quality of life [2]. Due to the chronic nature of $\mathrm{AD}$, both effectiveness and long-term safety should be taken into account when choosing a treatment. In most patients, $\mathrm{AD}$ is mild or moderate. In these cases, the therapy is based on the use of emollients and topical anti-inflammatory drugs $[3,4]$.

\section{EMOLLIENTS}

Emollients are the basis for the effective treatment of AD. The legitimacy of using emollients in this disease is indisputable. Neglect in the field of emollient therapy is one of the most common causes of treatment failures in $\mathrm{AD}[5,6]$. By creating a protective layer on the skin's surface, emollients reduce the transepidermal water loss (TEWL), which improves the level of skin hydration and lubrication. In addition, these preparations protect the skin against penetration of allergens and destructive effects of detergents. The duration of action of emollients on the skin is from 4 to 6 hours, therefore there is a need for sufficiently frequent application of these preparations $[7,8]$.

When choosing emollients, both effectiveness of these preparations in individual patients, as well as their safety should be taken into account. Considering the possibility of developing contact allergy to these products, emollients should be used that contain the lowest possible amount of chemical compounds with potential allergenic properties. Using emollients directly on inflammatory lesions should be avoided, as this may increase itching and burning sensation of the skin. In these cases, it is necessary to apply topical anti-inflammatory drugs beforehand $[9,10]$.

The proper use of emollients in the treatment of $\mathrm{AD}$ not only reduces itching and inflammation, but also extends periods of remission and reduces the use of topical glucocorticoids - tGSs (steroid sparing effect) [5].

\section{WPROWADZENIE}

Atopowe zapalenie skóry (AZS) jest najczęstszą dermatozą zapalną. Cechuje się przewlekłym i nawrotowym przebiegiem, obecnością na skórze zmian w postaci wyprysku oraz dokuczliwym świądem. Złożony patomechanizm choroby obejmuje uwarunkowania genetyczne, czynniki środowiskowe, zaburzenia mikrobiomu oraz zaburzenia immunologiczne [1].

Dotychczas nie ma metod terapeutycznych, które umożliwiają całkowite wyleczenie AZS. Leczenie, które podejmujemy, ma za zadanie uzyskanie jak najdłuższych remisji zmian zapalnych i ustąpienie świądu, a także poprawę jakości życia chorego [2]. Ze względu na przewlekły charakter choroby w wyborze metody terapii należy brać pod uwagę zarówno skuteczność, jak i bezpieczeństwo w perspektywie długofalowej. U większości chorych AZS przebiega w sposób łagodny lub umiarkowany. W tych przypadkach leczenie opiera się na stosowaniu emolientów oraz miejscowych leków przeciwzapalnych [3, 4].

\section{EMOLIENTY}

Emolienty stanowią podstawę skutecznego leczenia AZS. Zasadność stosowania emolientów w tej chorobie jest bezsporna. Zaniedbania w zakresie terapii emolientowej są jedną z najczęstszych przyczyn niepowodzeń leczenia AZS [5, 6]. Emolienty, tworząc na powierzchni skóry warstwę ochronną, powodują zmniejszenie przeznaskórkowej utraty wody (transepidermal water loss - TEWL), dzięki czemu poprawia się stopień nawilżenia i natłuszczenia skóry. Ponadto preparaty te chronią skórę przed przenikaniem alergenów oraz destrukcyjnym działaniem detergentów. Czas działania emolientów na skórę wynosi od 4 do 6 godzin, dlatego konieczne jest odpowiednio częste ich stosowanie $[7,8]$.

W wyborze emolientów należy się kierować zarówno skutecznością tych preparatów u poszczególnych chorych, jak i ich bezpieczeństwem. Ze względu na możliwość rozwoju uczulenia kontaktowego należy stosować emolienty zawierające jak najmniejszą liczbę związków chemicznych o potencjalnych właściwościach alergizujących. Trzeba również unikać stosowania emolientów bezpośrednio na zmiany zapalne, gdyż może to spowodować nasilenie świądu i pieczenia skóry. W takich przypadkach konieczne jest wcześniejsze zastosowanie miejscowych leków przeciwzapalnych $[9,10]$.

Właściwe stosowanie emolientów w leczeniu AZS nie tylko pozwala na ograniczenie świądu i zmniejszenie nasilenia stanu zapalnego, lecz także na wydłużenie okresów remisji oraz ograniczenie stosowania miejscowych glikokortykosteroidów - mGKS (steroid sparing effect) [5]. 


\section{WET-WRAP TREATMENT}

A form of emollient therapy, particularly useful in young children, is the use of wet-wrap treatment (WWT), which effectively protects the skin against scratching [6]. The WWT method is based on the use of two layers of dressings. The moist inner layer, applied to the skin immediately after the patient's bath, is soaked in emollient and/or diluted tGC (this form is reserved only for severe $\mathrm{AD}$ ), and then covered with a dry layer. Instead of soaking the dressing with the medicinal substance, it can be applied directly to the skin, and then covered with the wet and dry dressings. The use of double layers of dressings has a cooling effect, reduces itching, prolongs the moisturizing effect, resulting in faster disappearance of inflammatory skin lesions. This simple, safe and effective method of therapy is usually well tolerated by children and significantly improves the quality of sleep of young patients and their families [11, 12]. The use of tGCs in wet dressings, due to their possible greater absorption, should be performed under the supervision of a dermatologist experienced in this method and usually carried out during hospitalization.

\section{LOCAL ANTI-INFLAMMATORY THERAPY}

Local anti-inflammatory therapy in AD is currently based on the use of tGCs and topical calcineurin inhibitors (tCIs).

Topical steroid preparations have been used in dermatological treatment since the beginning of the 1950s. The first preparation successfully used in the treatment of $\mathrm{AD}$ was hydrocortisone acetate. Chemical modifications of this compound allowed for obtaining many more potent derivatives. The mechanism of action of all tGCs results from the stimulation or inhibition of synthesis of many biologically active substances, changes in vascular permeability and restriction of influx of inflammatory cells to the site of the inflammatory process [13]. In selecting the appropriate steroid preparation in a patient with $\mathrm{AD}$, potency of the drug, location and extent of skin lesions, nature of eczema (acute, subacute, chronic) as well as the patient's age should be taken into account $[5,6]$.

Despite introduction of novel therapeutic methods, topical glucocorticoids remain the basis of anti-inflammatory therapy in AD. These drugs allow for a very good therapeutic effect in a large group of patients with mild and moderate AD [9, 14, 15]. A limitation in the use of tGCs is the possibility of development of side effects, especially with their chronic application. In these cases, symptoms such as permanent vasodilation, skin atrophy, perioral inflammation (dermatitis perioralis), pigmentation disorders,

\section{MOKRE OPATRUNKI}

Formą terapii emolientowej, przydatną szczególnie u małych dzieci, jest stosowanie mokrych opatrunków (wet-wrap treatment - WWT), które skutecznie chronią skórę przed drapaniem [6]. Metoda WWT polega na nałożeniu dwóch warstw opatrunków. Warstwa wewnętrzna - wilgotna, stosowana na skórę bezpośrednio po kąpieli, jest nasączona emolientem i/lub rozcieńczonym mGKS (wyłącznie w przypadku ciężkich postaci AZS), a następnie pokrywana warstwą suchą. Zamiast nasączać opatrunek substancją leczniczą można zastosować ją bezpośrednio na skórę, a następnie na nią nakładać mokry, a potem suchy opatrunek. Stosowanie podwójnych warstw opatrunków wywołuje efekt chłodzący, zmniejsza uczucie świądu, przedłuża efekt nawilżenia, dzięki czemu uzyskuje się szybsze ustępowanie zmian zapalnych skóry. Ta prosta, bezpieczna i skuteczna metoda terapii jest zwykle dobrze tolerowana przez dzieci i istotnie poprawia jakość snu małych pacjentów oraz ich rodzin $[11,12]$. Stosowanie mGKS w mokrych opatrunkach ze względu na możliwość ich większego wchłaniania powinno być wykonywane pod nadzorem doświadczonego $\mathrm{w}$ tej metodzie dermatologa i zwykle prowadzone jest podczas hospitalizacji.

\section{MIEJSCOWA TERAPIA PRZECIWZAPALNA}

Miejscowa terapia przeciwzapalna w AZS opiera się aktualnie na stosowaniu mGKS oraz miejscowych inhibitorów kalcyneuryny (mIK).

Miejscowe preparaty steroidowe są wykorzystywane w lecznictwie dermatologicznym od początku lat 50. XX wieku. Pierwszym lekiem zastosowanym z powodzeniem w leczeniu AZS był octan hydrokortyzonu. Modyfikacje chemiczne tego związku pozwoliły na uzyskanie wielu silniej działających pochodnych. Mechanizm działania wszystkich mGKS wynika z pobudzania lub hamowania syntezy wielu biologicznie aktywnych substancji, zmiany w zakresie przepuszczalności naczyń oraz ograniczenia napływu komórek zapalnych do miejsca, w którym toczy się proces zapalny [13]. W wyborze odpowiedniego preparatu steroidowego u pacjenta z AZS należy brać pod uwagę siłę działania leku, umiejscowienie i rozległość zmian skórnych, charakter wyprysku (ostry, podostry, przewlekły), jak również wiek chorego $[5,6]$.

Miejscowe glikokortykosteroidy, pomimo wprowadzania nowych metod leczenia, stanowią podstawę terapii przeciwzapalnej w AZS. Leki te pozwalają na uzyskanie bardzo dobrego efektu terapeutycznego u dużej grupy chorych $\mathrm{z}$ lagodną i umiarkowaną postacią AZS [9, 14, 15]. Ograniczeniem stosowania mGKS jest możliwość wystąpienia działań niepożądanych, zwłaszcza przy ich przewlekłej aplikacji. 
hypertrichosis, skin infections, withdrawal effect or the phenomenon of tachyphylaxis may develop [6, 7]. In exceptional cases, when strong tGCs are used on large areas of the skin in young children, especially infants, systemic steroid therapy complications may occur, such as osteoporosis, growth inhibition or suppression of the hypothalamic-pituitary-adrenal axis [7].

One of the ways to reduce adverse effects of local steroid therapy is to replace continuous (daily) application of these preparations, with an intermittent therapy consisting in the use of tGCs for 2-3 days a week, alternating with emollients [7]. Using these preparations several times during the day should also be avoided. Numerous studies have shown that one-time topical application allows for the same effectiveness as twice-a-day therapy, with increased safety [16]. Unfortunately, many patients, fearing adverse effects of tGCs, avoid them. Proper cooperation between the patient and the doctor, especially the parent/guardian of an atopic child, cannot be overestimated. Only if the patient receives precise instructions on the principles of safe steroid therapy and trusts the doctor, can he/she achieve the optimal therapeutic effect $[6,17,18]$.

Topical calcineurin inhibitors: pimecrolimus and tacrolimus, introduced for treatment much later than tGCs - at the turn of the $20^{\text {th }}$ and $21^{\text {st }}$ centuries are an important weapon in the local treatment of AD. These are immunomodulating drugs that affect the abnormal immune response underlying the chronic inflammatory process. These preparations are especially useful in situations when tGCs are contraindicated or poorly tolerated. Moreover, in many cases, continuation of therapy with these drugs after the acute inflammation has been controlled by tGCs, allows for the shortening of local steroid therapy, and thus for the improvement of safety of the treatment $[6,17]$. Pimecrolimus is a $1 \%$ cream and is recommended for the treatment of mild and moderate AD. Tacrolimus is an ointment available in two concentrations: $0.03 \%$ and $0.1 \%$; its use is indicated in moderate and severe atopic lesions $[6,18]$. Calcineurin inhibitors are applied twice daily to eczema lesions until their resolution. Unlike tGCs, these preparations can be used chronically, without fear of their adverse effects, because they do not damage collagen nor the epidermal barrier, and even with chronic application they increase the thickness of the skin and stimulate collagen synthesis in places showing posterior skin atrophy. Safety of tCIs is particularly important when applied to areas of the skin such as the face, including the eyelids, as well as the neck and skin folds or the genital area, that is wherever the use of tGCs is contraindicated $[6,19]$. Long-term treatment with tCIs in patients from 2 years of age has been shown to be
W tych przypadkach może dojść do rozwoju takich objawów, jak trwałe rozszerzenie naczyń krwionośnych, atrofia skóry, zapalenie okołoustne (dermatitis perioralis), zaburzenia pigmentacji, hipertrychoza, infekcje skóry, efekt $\mathrm{z}$ odstawienia lub zjawisko tachyfilaksji $[6,7]$. W wyjątkowych przypadkach, przy stosowaniu silnych mGKS na duże powierzchnie skóry u małych dzieci, zwłaszcza niemowląt, może dochodzić do ogólnych powikłań steroidoterapii, takich jak osteoporoza, zahamowanie wzrostu lub hamowanie osi podwzgórze-przysadka-nadnercza [7].

Jednym ze sposobów ograniczenia objawów niepożądanych miejscowej steroidoterapii jest zastąpienie terapii ciągłej (codziennej) terapią przerywaną, polegającą na stosowaniu mGKS przez 2-3 dni w tygodniu, na przemian z emolientami [7]. Należy również unikać kilkakrotnego stosowania tych preparatów w ciągu dnia. Liczne badania wykazały, że jednorazowa aplikacja miejscowa pozwala na uzyskanie takiej samej skuteczności jak aplikacja 2 razy dziennie, przy zwiększeniu bezpieczeństwa [16]. Niestety wielu pacjentów z obawy przed działaniami niepożądanymi mGKS unika ich stosowania. Nie do przecenienia jest tu właściwa współpraca lekarza z pacjentem, zwłaszcza z rodzicem lub opiekunem dziecka $z$ atopią. Jedynie jeżeli pacjent otrzyma dokładne wskazówki na temat zasad bezpiecznej steroidoterapii i zaufa lekarzowi, ma szansę osiągnąć optymalny efekt terapeutyczny $[6,17,18]$.

Miejscowe inhibitory kalcyneuryny: pimekrolimus i takrolimus, wprowadzone do leczenia znacznie później niż mGKS, bo na przełomie XX i XXI wieku, stanowią ważną broń w miejscowej terapii AZS. Są to leki immunomodulujące, wpływające na nieprawidłową odpowiedź immunologiczną, która leży u podstaw przewlekłego procesu zapalnego. Preparaty te są szczególnie przydatne, gdy mGKS są przeciwwskazane lub źle tolerowane. Ponadto w wielu przypadkach kontynuowanie terapii tymi lekami po opanowaniu ostrego stanu zapalnego przez mGKS pozwala na skrócenie stosowania steroidoterapii miejscowej, a także poprawę bezpieczeństwa leczenia $[6,17]$. Pimekrolimus ma postać $1 \%$ kremu, zalecany jest do leczenia łagodnych i umiarkowanych postaci AZS. Takrolimus występuje w formie maści w dwóch stężeniach: 0,03\% i 0,1\%. Wskazaniem do jego stosowania są umiarkowane i nasilone zmiany atopowe $[6,18]$. Inhibitory kalcyneuryny aplikuje się 2 razy dziennie na zmiany wypryskowe do czasu ich ustąpienia. W przeciwieństwie do mGKS preparaty te można stosować przewlekle bez obawy o działania niepożądane, gdyż nie niszczą włókien kolagenowych i nie powodują uszkodzenia bariery naskórkowej, a wręcz przeciwnie, przy przewlekłej aplikacji zwiększają grubość skóry i pobudzają syntezę kolagenu w miejscach z posteroidowymi zanikami skóry. Szczególnie ważne jest bezpieczeństwo 
effective, safe and well-tolerated. The most common adverse effect associated with the use of these drugs is a transient burning sensation of the skin at the site of their application $[6,7]$.

A newer and recommended form of tCIs application is the proactive (maintenance) therapy. It involves the use of tacrolimus twice a week after achieving remission, in places of previous inflammatory skin lesions. This method of treatment enables long-term control of the disease; allows to reduce the frequency of $\mathrm{AD}$ exacerbations in comparison to traditional therapy, i.e., the use of $\mathrm{tCIs}$ only during periods of active skin inflammation (active therapy) $[20,21]$. For a long time, however, this form of therapy aroused emotions among patients, especially parents of young children, as well as some doctors, due to the disturbing record that appeared in 2003 in the SmPC of tacrolimus, mentioning a possible development of malignancies, including lymphoma and skin cancers, in patients using tacrolimus ointment. Since then, dozens of clinical trials have been conducted to assess the safety of this product. None of them confirmed this risk [17, 20, 22-24].

\section{CRISABOROLE}

One of the new therapeutic options is crisaborole a non-steroidal anti-inflammatory drug, a phosphodiesterase 4 (PDE-4) inhibitor. PDE-4 belongs to one of the families (classes) of phosphodiesterases that catalyze the hydrolysis of cyclic AMP (cAMP) and play a key role in regulating intracellular cAMP. Reduction of cAMP levels leads to production and release of pro-inflammatory cytokines and chemokines, such as IL-2, IL-4, IL-31. This contributes to manifestation of symptoms of AD. The mechanism of anti-inflammatory effect of crisaborole that inhibits PDE-4 is due to the inhibition of secretion of these cytokines. The drug also improves protective function of the skin barrier [25]. Paller et al. confirmed efficacy and safety of crisaborole in children over 2 years of age with mild and moderate AD. The drug was used twice a day for 4 weeks, achieving a reduction in lesions on the Investigators' Global Assessment (IGA) scale and a significant reduction in itching after only 2 days of treatment. The agent was very well tolerated, and the only adverse effects were pain and infections at the site of drug application [26].

Similarly, Eichenfield et al. showed no significant adverse effects after a long-term, 48-week therapy with this drug [27]. Earlier studies on healthy volunteers showed good tolerance and no adverse effects of crisaborole when applied to delicate skin of anogenital and detrusive areas, as well as the skin of the face, where local steroid therapy is particularly avoided [28].
mIK przy stosowaniu na takie obszary skóry, jak twarz, w tym powieki, szyja oraz fałdy skóry czy okolice narządów płciowych, czyli wszędzie tam, gdzie mGKS są przeciwwskazane [6, 19]. Wykazano, że długotrwałe leczenie mIK pacjentów od 2. roku życia jest skuteczne, bezpieczne i dobrze tolerowane. Najczęstszym objawem niepożądanym związanym ze stosowaniem tych leków jest przejściowe pieczenie skóry w miejscu ich stosowania [6, 7].

Nowszą i rekomendowaną formą aplikacji mIK jest terapia proaktywna (podtrzymujacca). Polega ona na stosowaniu takrolimusu 2 razy w tygodniu po uzyskaniu remisji, w miejscach wcześniejszych zmian zapalnych skóry. Taki sposób leczenia umożliwia długotrwałą kontrolę choroby, pozwala na zmniejszenie częstości zaostrzeń AZS w porównaniu z terapią tradycyjną, czyli stosowaniem mIK wyłącznie w okresach aktywnego stanu zapalnego skóry (terapia aktywna) $[20,21]$. Ta forma leczenia przez długi czas budziła jednak emocje wśród pacjentów, szczególnie rodziców małych dzieci, jak również niektórych lekarzy z uwagi na niepokojący zapis, jaki pojawił się w 2003 roku w charakterystyce produktu leczniczego (ChPL), mówiący o możliwości rozwoju nowotworów złośliwych, w tym chłoniaka i raków skóry, u pacjentów stosujących maść z takrolimusem. Od tego czasu przeprowadzono kilkadziesiąt badań klinicznych mających na celu ocenę bezpieczeństwa tego produktu. W żadnym $\mathrm{z}$ przeprowadzonych badań nie potwierdzono tego niebezpieczeństwa [17, 20, 22-24].

\section{KRYZABOROL}

Jedną z nowych opcji terapeutycznych jest kryzaborol - niesteroidowy lek przeciwzapalny będący inhibitorem fosfodiesterazy 4 (PDE-4). PDE-4 należy do jednej z rodzin (klas) fosfodiesteraz, które katalizują hydrolizę cyklicznego AMP (cAMP) i odgrywają kluczową rolę w regulacji wewnątrzkomórkowego cAMP. Obniżenie poziomu cAMP prowadzi do produkcji i uwalniania prozapalnych cytokin i chemokin, takich jak IL-2, IL-4, IL-31, co przyczynia się do wystąpienia objawów AZS. Mechanizm przeciwzapalnego działania kryzaborolu hamującego PDE-4 wynika z hamowania wydzielania tych cytokin. Lek wpływa również na poprawę funkcji ochronnej bariery skórnej [25]. W badaniach Pallera i wsp. potwierdzono skuteczność i bezpieczeństwo kryzaborolu u dzieci powyżej 2. roku życia $z$ łagodnym i umiarkowanym AZS. Lek stosowano 2 razy dziennie przez 4 tygodnie, uzyskując redukcję zmian chorobowych w skali IGA (Investigators' Global Assessment) oraz istotne zmniejszenie świądu już po 2 dniach leczenia. Preparat był bardzo dobrze tolerowany, a jedynymi działaniami niepożądanymi były ból i infekcje w miejscu aplikacji leku [26]. 
In experimental studies assessing safety of crisaborole in animals (mice and rats) the use of high oral and topical doses of the drug was not associated with any adverse effects, including carcinogenic effects [29]. In 2019, results of 7 randomized trials with topical phosphodiesterase inhibitors were summarized. A total of 1,869 patients with mild and moderate AD were examined, and statistically significant improvement was achieved compared to the drug vehicle, both in dermatological assessment and in objective clinical scales [30]. In studies comparing the use of crisaborole in patients of different races, no ethnic differences in the effectiveness and tolerance of the drug were found [31].

In all publications available to date, efficacy of crisaborole in relation to placebo/drug vehicle was assessed. Fahrbach et al. conducted a meta-analysis based on 894 reports assessing the effectiveness of topical anti-inflammatory drugs in patients with mild and moderate $\mathrm{AD}$ and compared the effectiveness of previously used preparations and crisaborole in similar groups of patients. The assessment was made on the basis of the IGA scale. Results of the meta-analysis allowed the authors to conclude that crisaborole in the form of $2 \%$ ointment was more effective than $1 \%$ pimecrolimus cream, but was comparable to $0.1 \%$ and $0.003 \%$ tacrolimus ointment [32]

Recently, the first report was published assessing the correlation between clinical efficacy of crisaborole in patients with $\mathrm{AD}$ and the presentation of pathomorphological and immunological changes in the skin, based on the analysis of biopsies of skin lesions in these patients. The study was conducted in a group of 40 adult patients with mild and moderate AD. The authors showed a higher efficacy of $2 \%$ ointment containing crisaborole compared to the vehicle. This assessment was based on clinical scales: TSS (Total Sign Score), ISGA (Investigator's Static Global Assessment), PNRS (Pruritus Numeric Rating Scale) and the assessment of epidermal barrier function measured by TEWL. Clinical improvement in all patients correlated with the change in profile of cells in the inflammatory infiltrate. The above study confirmed the role of crisaborole in modulation of the local T-cell response in the skin and a change in the profile of secreted pro-inflammatory cytokines [33].

Results of all studies conducted so far indicate that crisaborole is an effective and safe alternative to the current topical anti-inflammatory drugs used in AD $[19,34]$. Crizaborole has been available in the USA since 2016 - the American Food and Drug Administration (FDA) has approved the preparation for the treatment of mild and moderate $\mathrm{AD}$ in patients from 2 years of age with involvement of up to $40 \%$ of the skin surface [26]. Previously, the drug was also ap-
Również Eichenfield i wsp. wykazali brak istotnych działań niepożądanych po długoterminowej, 48-tygodniowej terapii kryzaborolem [27]. We wcześniejszych badaniach u zdrowych ochotników stwierdzono dobrą tolerancję i brak działań niepożądanych kryzaborolu stosowanego na delikatną skórę okolic anogenitalnych, wyprzeniowych, a także skórę twarzy, gdzie szczególnie unika się miejscowej steroidoterapii [28].

W badaniach doświadczalnych oceniających bezpieczeństwo kryzaborolu u zwierząt (myszy i szczury) stosowanie wysokich dawek doustnych i miejscowych leku nie wiązało się z wystąpieniem żadnych efektów niepożądanych, w tym działania kancerogennego [29]. W 2019 roku podsumowano wyniki 7 badań $\mathrm{z}$ randomizacją z użyciem miejscowych inhibitorów fosfodiesterazy. Przebadano łącznie grupe 1869 chorych z łagodną i umiarkowaną postacią AZS i uzyskano statystycznie istotną poprawę w porównaniu z podłożem leku zarówno w ocenie dermatologicznej, jak i w obiektywnych skalach klinicznych [30]. W badaniach porównujących stosowanie kryzaborolu u pacjentów różnych ras nie wykazano różnic dotyczących skuteczności i tolerancji leku [31].

We wszystkich dostępnych publikacjach dokonywano oceny skuteczności kryzaborolu w stosunku do placebo lub podłoża leku. Fahrbach i wsp. przeprowadzili metaanalizę, opierając się na 894 doniesieniach oceniających skuteczność miejscowych leków przeciwzapalnych u chorych z łagodną i umiarkowaną postacią AZS, i porównali skuteczność wcześniej stosowanych preparatów i kryzaborolu w podobnych grupach pacjentów. Oceny dokonywano według skali IGA. Wyniki metaanalizy pozwoliły autorom na sformułowanie konkluzji, że kryzaborol w postaci 2\% maści wykazuje wyższą skuteczność niż 1\% pimekrolimus w kremie, jest natomiast porównywalny z 0,1\% i 0,003\% takrolimusem w maści [32].

Ostatnio opublikowano także pierwsze doniesienie oceniające na podstawie analizy biopsji ze zmian skórnych korelację między skutecznością kliniczną kryzaborolu u chorych z AZS i obrazem zmian patomorfologicznych i immunologicznych w skórze. Badania przeprowadzono w grupie 40 dorosłych chorych z łagodną i umiarkowaną postacią AZS. Autorzy wykazali wyższą skuteczność $2 \%$ maści zawierającej kryzaborol w porównaniu z podłożem preparatu. Ocena opierała się na następujących skalach klinicznych: TSS (Total Sign Score), ISGA (Investigator's Static Global Assessment), PNRS (Pruritus Numeric Rating Scale), a także ocenie funkcji bariery naskórkowej mierzonej TEWL. Poprawa kliniczna u wszystkich chorych korelowała ze zmianą profilu komórek w nacieku zapalnym. Powyższe badania potwierdziły rolę kryzaborolu w modulacji miejscowej odpowiedzi T-komórkowej w skórze i zmianę profilu wydzielanych cytokin prozapalnych [33]. 
proved for the treatment of AD in Australia, Canada and Israel. In Europe, crisaborole ointment will be available after approval by the European Medicines Agency (EMA).

\section{NEW PERSPECTIVES OF ANTI-INFLAMMATORY TREATMENT IN ATOPIC DERMATITIS}

\section{JAK-STAT inhibitors}

These drugs block activation of Janus kinases, transduction of the signal to the nucleus and, consequently, transcription of many pro-inflammatory cytokines. Phase II randomized trials assessed efficacy and safety of ruxolitinib cream (a selective JAK1 and JAK 2 inhibitor) at the concentration of $0.15 \%$ to $1.5 \%$ in 307 adult patients with mild and moderate AD. Rapid resolution of pruritus within 36 hours of treatment, as well as improved quality of life with good drug tolerance were observed [35].

Another topical JAK inhibitor is delgocitinib. In the phase II study with the use of this drug in form of an ointment at concentrations of $0.25 \%, 0.5 \%, 1 \%, 3 \%$ applied twice a day in a group of 327 adult patients with moderate and severe AD, a significant improvement in clinical symptoms and a reduction in severity of itch, with a favorable safety profile were shown [36]. A similar study conducted in a group of 103 children from 2 to 15 years of age, with AD, with $0.25 \%$ and $0.5 \%$ delgocitinib ointment twice a day showed an improvement in clinical signs and symptoms [37]. The same authors published favorable results of the phase III trial using $0.5 \%$ delgocitinib ointment versus placebo (ointment vehicle) in a population of 158 patients from 16 years of age with moderate to severe AD [38].

Tofacitinib is a nonselective JAK $1 / 3$ inhibitor applied topically in the form of a $2 \%$ ointment. The phase IIa study enrolled 69 patients with mild to moderate AD. The results obtained after 4 weeks of topical therapy showed a much greater clinical efficacy of the drug compared to placebo, with an early onset of action (improvement in itching observed already after 2 days of therapy) [39].

Another biological drug, cerdulatinib, is a selective JAK and SYK (Spleen tyrosine kinase) inhibitor. In phase II clinical trials with the use of the above preparation in the form of $0.4 \%$ topical gel, a reduction in clinical symptoms was observed, assessed with the EASI (Eczema Area and Severity Index) scale [40].

It is to be hoped that in the near future, studies of all these preparations will come to a successful conclusion, thanks to which the portfolio of effective and safe drugs for an ever wider group of patients with AD will significantly expand.
Wyniki wszystkich dotychczasowych badań wskazują, że kryzaborol jest skuteczną i bezpieczną alternatywą dla dotychczasowych miejscowych leków przeciwzapalnych stosowanych w AZS [19, 34]. Kryzaborol jest od 2016 roku dostępny w USA - amerykańska Agencja ds. Żywności i Leków (Food and Drug Administration - FDA) zatwierdziła preparat do leczenia łagodnego i umiarkowanego AZS u pacjentów od 2. roku życia przy zajęciu do $40 \%$ powierzchni skóry [26]. Wcześniej lek został też zatwierdzony do terapii AZS w Australii, Kanadzie i Izraelu. W Europie kryzaborol w postaci maści będzie dostępny po zatwierdzeniu przez Europejską Agencję Leków (European Medicines Agency - EMA).

\section{NOWE PERSPEKTYWY LECZENIA PRZECIWZAPALNEGO W ATOPOWYM ZAPALENIU SKÓRY}

\section{Inhibitory JAK-STAT}

Leki te blokują aktywację kinaz janusowych, przemieszczanie sygnału do jądra komórkowego, a także transkrypcję wielu cytokin prozapalnych. W badaniach z randomizacją fazy II oceniono skuteczność i bezpieczeństwo kremu z ruksolitynibem (selektywnym inhibitorem JAK1 i JAK2) w stężeniu od 0,15\% do 1,5\% u 307 dorosłych chorych z łagodnym i umiarkowanym AZS. Obserwowano szybkie ustępowanie świądu w czasie 36 godzin leczenia, poprawę jakości życia z jednoczesną dobrą tolerancją leku [35].

Inny lek miejscowy z grupy inhibitorów JAK to delgocytynib. W badaniu fazy II z użyciem tego leku w postaci maści w stężeniach $0,25 \%, 0,5 \%, 1 \%, 3 \%$ stosowanej 2 razy dziennie u 327 pacjentów dorosłych z umiarkowanym i ciężkim AZS stwierdzono istotną poprawę objawów klinicznych i zmniejszenie nasilenia świądu, przy jednoczesnym korzystnym profilu bezpieczeństwa [36]. Podobne badanie prowadzone w grupie 103 dzieci od 2. do 15. roku życia z AZS z użyciem 0,25\% i 0,5\% maści z delgocytynibem stosowanej 2 razy dziennie wykazało poprawe klinicznych objawów podmiotowych i przedmiotowych [37]. Ci sami autorzy opublikowali korzystne wyniki badania fazy III z zastosowaniem 0,5\% maści $\mathrm{z}$ delgocytynibem $\mathrm{w}$ porównaniu $\mathrm{z}$ placebo (podłoże maści) w populacji 158 chorych od 16. roku życia z umiarkowanym i ciężkim AZS [38].

Tofacytynib to nieselektywny inhibitor JAK1/3 stosowany miejscowo w postaci $2 \%$ maści. Do badania fazy IIa włączono 69 pacjentów z łagodnym i umiarkowanym AZS. Wyniki uzyskane po 4 tygodniach terapii miejscowej wykazały znacznie większą skuteczność kliniczną leku niż placebo, z wczesnym początkiem działania (poprawa w zakresie świądu obserwowana już po 2 dniach terapii) [39]. 


\section{CONFLICT OF INTEREST}

The authors declare no conflict of interest.
Inny lek biologiczny - cerdulatynib - to selektywny inhibitor JAK i SYK (spleen tyrosine kinase). W badaniach klinicznych fazy II z użyciem powyższego preparatu w postaci $0,4 \%$ żelu do stosowania miejscowego zaobserwowano redukcję objawów klinicznych ocenianych na podstawie skali EASI (Eczema Area and Severity Index) [40].

Należy mieć nadzieję, że w najbliższym czasie badania wszystkich tych preparatów zakończą się pomyślnie, dzięki czemu znacznie poszerzy się portfolio skutecznych i bezpiecznych leków dla coraz szerszej grupy pacjentów z AZS.

\section{KONFLIKT INTERESÓW}

Autorzy nie zgłaszają konfliktu interesów.

\section{References}

\section{Piśmiennictwo}

1. Feldman S.R., Cox L.S., Strowd L.C.: The challenge of managing atopic dermatitis in the United States. Am Health Drug Benefits 2019, 12, 83-93.

2. Eichenfield L.F., Tom W.L., Berger T.G., Krol A., Paller A.S., Schwarzenberger K., et al.: Guidelines of care for the management of atopic dermatitis: section 2. Management and treatment of atopic dermatitis with topical therapies. J Am Acad Dermatol 2014, 71, 116-132.

3. Silverberg J.I., Simpson E.L.: Association between severe eczema in children and multiple comorbid conditions and increased healthcare utilization. Pediatr Allergy Immunol 2013, 24, 476-486.

4. Chiesa Fuxench Z.C., Block J.K., Boguniewicz M., Boyle J., Fonacier L., Gelfand J.M., et al.: Atopic dermatitis in America study: a cross-sectional study examining the prevalence and disease burden of atopic dermatitis in the US adult population. J Invest Dermatol 2019, 139, 583-590.

5. Nowicki R.J.: Postępowanie podstawowe. In: Atopowe zapalenie skóry. R. Nowicki (ed.). Medical Education, Warszawa, 2017, 97-100.

6. Nowicki R.J., Trzeciak M., Kaczmarski M., Wilkowska A., Czarnecka-Operacz M., Kowalewski C., et al.: Atopowe zapalenie skóry. Interdyscyplinarne rekomendacje diagnostyczno-terapeutyczne Polskiego Towarzystwa Dermatologicznego, Polskiego Towarzystwa Alergologicznego. Polskiego Towarzystwa Pediatrycznego oraz Polskiego Towarzystwa Medycyny Rodzinnej. Część I. Profilaktyka, leczenie miejscowe i fototerapia. Dermatol Rev 2019, 4, 1-11.

7. Wollenberg A., Oranje A., Deleuran M., Simon D., Szalai Z., Kunz B., et al.: ETFAD/EADV Eczema task force 2015 position paper on diagnosis and treatment of atopic dermatitis in adults and paediatric patients. J Eur Acad Dermatol Venereol 2016, 30, 729-747.

8. Szepietowski J., Kaszuba A., Adamski Z., Placek W., Salomon J.: Emolienty w leczeniu schorzeń dermatologicznych: stanowisko grupy ekspertów. Dermatol Klin 2011, 13, 209-214.

9. Ring J., Alomar A., Bieber T., Deleuran M., Fink-Wagner A., Gelmetti C., et al.: Guidelines for treatment of atopic eczema (atopic dermatitis). Part I. J Eur Acad Dermatol Venereol 2012, 26, 1045-1060.

10. Raone B., Ravaioli G.M., Dika E., Gurioli C., Patrizi A.: The use of emollients for atopic eczema. Austin J Allergy 2015, 2, 1018-1025.

11. Arjan C.A., Devillers A., Oranje A.P.: Wet-wrap treatment in children with atopic dermatitis; a practical guideline. Pediatr Dermatol 2012, 29, 24-27.

12. Oranje A.P., Devillers A.C., Kunz B., Jones S.L., DeRaeve L., Van Gysel D., et al.: Treatment of patients with atopic dermatitis. Using wet-wrap dressing with dilutes steroids/ or emollients. An expert-panel's opinion and review of the literature. J Eur Acad Dermatol Venereol 2006, 20, 1277-1286.

13. Cisło M., Kozłowska A., Nockowski P.: Zasady leczenia miejscowego. In: Terapia w dermatologii. J. Szepietowski, W. Baran (eds.). PZWL, Warszawa, 2019, 17-26.

14. Aoki V., Lorenzini D., Orfali R.L., Zaniboni M.C., de Oliveira Z.N.P., Rivitti-Machado M.C., et al.: Consensus on the therapeutic management of atopic dermatitis - Brazilian Society of Dermatology. An Bras Dermatol 2019, 94 (2 Suppl 1), 67-75.

15. Mohan G.C., Lio P.A.: Comparison of dermatology and allergy guidelines for atopic dermatitis management. JAMA Dermatol 2015, 151, 1009-1013.

16. Green C., Colquitt J.L., Kirby J., Davidson P.: Topical corticosteroids for atopic eczema: clinical and cost of once-daily vs. more frequent use. Br J Dermatol 2005, 152, 130-141.

17. Wollenberg A., Barbarot S., Bieber T., Christen-Zaech S., Deleuran M., Fink-Wagner A., et al.: Consensus-based European guidelines for treatment of atopic eczema (atopic dermatitis) in adults and children: part I. J Eur Acad Dermatol Venereol $2018,32,657-682$.

18. Charman C.R., Morris A.D., Williams H.C.: Topical corticosteroid phobia in patients with atopic eczema. Br J Dermatol 2000, $142,931-936$ 
19. Draelos Z.D., Feldman S.R., Berman B.: Tolerability of topical treatments for atopic dermatitis. Dermatol Ther (Heidelb) 2019, 9, 71-102.

20. Wollenberg A., Bieber T.: Proactive therapy of atopic dermatitis - an emerging concept. Allergy 2009, 64, $276-278$.

21. Trzeciak M.: Terapia proaktywna. In: Atopowe zapalenie skóry. R. Nowicki (ed.). Medical Education, Warszawa, 2017, 111116.

22. Segal A.O., Allis A.K., Kim H.L.: CSACI position statement: safety of topical calcineurin-inhibitors in the management of atopic dermatitis in children and adults. Allergy Asthma Clin Immunol 2013, 9, 24.

23. Sokołowska-Wojdyło M., Góralczyk A., Barańska-Rybak W., Szczerkowska-Dobosz A.: Cancerogenic effect of topical calcineurin inhibitors - a real threat or invalid concerns? Dermatol Rev 2012, 99, 625-631.

24. Paller A.S., Fölster-Holst R., Hen S.C., Diepgen T.L., Elmets C., Margolis D.J., et al.: No evidence of increased cancer incidence in children using topical tacrolimus for atopic dermatitis. J Am Acad Dermatol 2020, 83, 375-381.

25. Fisbein A.B., Silvarberg J.I., Wilson E.J., Ong P.Y.: Update on atopic dermatitis: diagnosis, severity assessment and treatment selection. J Allergy Clin Immunol Pract 2020, 8, 91-101.

26. Paller A.S., Tom W.L., Lebwohl M.G., Blumenthal R.L., Boguniewicz M., Call R.S., et al.: Efficacy and safety of crisaborole ointment, a novel, nonsteroidal phosphodiesterase 4 (PDE4) inhibitor for the topical treatment of atopic dermatitis (AD) in children and adults. J Am Acad Dermatol 2016, 75, 494-503.

27. Eichenfield L.F., Call R.S., Forsha D.W., Fowler Jr J., Hebert A.A., Spellman M., et al.: Long-term safety of crisaborole ointment $2 \%$ in children and adults with mild to moderate atopic dermatitis. J Am Acad Dermatol 2017, 77, 641-649.

28. Zane L.T., Hughes M.H., Shakib S.: Tolerability of crisaborole ointment for application on sensitive skin areas: a randomized, double-blind, vehicle-controlled study in healthy volunteers. Am J Clin Dermatol 2016, 17, 519-526.

29. Ciaravino V., Coronado D., Lanphear C., Chanda S.: 2-Year animal carcinogenicity results for crisaborole, a novel phosphodiesterase 4 inhibitor for atopic dermatitis. J Dermatol Sci 2017, 87, 116-122.

30. Yang H., Wang J., Zhang X., Zhang Y., Qin Z.L., Wang H., et al.: Application of topical phosphodiesterase 4 inhibitors in mild to moderate atopic dermatitis. JAMA Dermatol 2019, 155, 585-593.

31. Callender V., Alexis A.F., Stein Gold L.F.: Efficacy and safety of crisaborole ointment, $2 \%$, for the treatment of mild-to-moderate atopic dermatitis across racial and ethnic groups. Am J Clin Dermatol 2019, 20, 711-723.

32. Fahrbach K., Tarpey J., Washington E.B., Hughes R., Thom H., Neary M.P., et al.: Crisaborole ointment, $2 \%$, for treatment of patients with mild-to-moderate atopic dermatitis: systematic literature review and network meta-analysis. Dermatol Ther (Heidelb) 2020, 10, 681-694.

33. Bissonnette R., Pavel A.B., Diaz A., Werth J.L., Zang C., Vranic I., et al.: Crisaborole and atopic dermatitis skin biomarkers: an intrapatient randomized trial. J Allergy Clin Immunol 2019, 144, 1274-89.

34. Papier A., Strowd L.C.: Atopic dermatitis: a review of topical nonsteroid therapy. Drugs Context 2018, 7, 212521.

35. Kim B.S., Sun K., Papp K., Venturanza M., Nasir A., Kuligowski M.E.: Effects of ruxolitinib cream on pruritus and quality of life in atopic dermatitis: results from a phase 2, randomized, dose-ranging, vehicle- and active-controlled study. J Am Acad Dermatol 2020, 82, 1305-1313.

36. Nakagawa H., Nemoto O., Igarashi A., Nagata T.: Efficacy and safety of topical JTE-052, a Janus kinase inhibitor, in Japanese adult patients with moderate-to-severe atopic dermatitis: a phase II, multicentre, randomized, vehicle-controlled clinical study. Br J Dermatol 2018, 178, 424-432.

37. Nakagawa H., Nemoto O., Igarashi A., Saeki H., Oda M., Kabashima K., et al.: Phase 2 clinical study of delgocitinib ointment in pediatric patients with atopic dermatitis. J Allergy Clin Immunol 2019, 144, 1575-1583.

38. Nakagawa H., Nemoto O., Igarashi A., Saeki H., Kaino H., Nagata T.: Delgocitinib ointment, a topical Janus kinase inhibitor, in adult patients with moderate to severe atopic dermatitis: a phase 3, randomized, double-blind, vehicle-controlled study and an open-label, long-term extension study. J Am Acad Dermatol 2020, 82, 823-831.

39. Bissonnette R., Papp K.A., Poulin Y., Gooderham M., Raman M., Mallbris L., et al.: Topical tofacitinib for atopic dermatitis: a phase IIa randomized trial. Br J Dermatol 2016, 175, 902-911.

40. Piscitelli S., Lee J., McHale K., Jett J.E.: Cerdulatinib (DMVT-502), a novel, topical dual Janus kinase/spleen tyrosine kinase inhibitor, improves the cellular and molecular cutaneous signature in patients with atopic dermatitis. Exp Dermatol 2018,27, S2.

Received: 28.11 .2020

Accepted: 4.02 .2021

Otrzymano: $28.11 .2020 \mathrm{r}$.

Zaakceptowano: 4.02.2021 r.

How to cite this article

Nowicki R.J., Grubska-Suchanek E., Trzeciak M., Wilkowska A.: Current options and perspectives for the topical treatment of atopic dermatitis. Dermatol Rev/Przegl Dermatol 2021, 108, 117-125. DOI: https://doi.org/10.5114/dr.2021.107283. 